\title{
A Comparative Study of Library Surveys of Internet Users at Seton Hall University in 1998 and 2001
}

\section{Xue-Ming Bao}

\begin{abstract}
This article compares data collected in library surveys of Internet users at Seton Hall University in 1998 and 2001. The aim of the comparison is to provide information on changes in library users' Internet use behavior, satisfaction levels, and problems in using the Internet. The response distribution of the people in different categories represents the population of Seton Hall University in approximate proportions in both surveys. This article discusses the challenges that were met with visible, moderate, and no improvements. It points out what remains to be the major challenge for librarians.
\end{abstract}

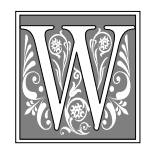

hat changes have occurred with regard to the Internet as a component of electronic services in academic libraries in the past five years? In a 1996 ALA survey, Mary J. Lynch reported that 87 percent of the academic libraries in doctorate-granting institutions included in the survey provided information access through home pages on the World Wide Web, 84 percent provided formal Internet training for faculty, and 90 percent provided student training. ${ }^{1}$ A sign of change was reflected in Mick O'Leary's article, "New Academic Information Model Bypasses Libraries," published in $2001 .^{2} \mathrm{He}$ wrote that several ambitious, well-founded information distributors such as XanEdu, Questia, and Ebrary seek to replace the library-vendor partnership with new channels that cut the library out of the loop. On the other hand, Mark Y. Herring gave ten reasons why the Internet is no substitute for a library in an article published in April 2001. ${ }^{3}$ Herring asserted that the Internet has not made libraries obsolete.

The author conducted a library survey of Internet users at Seton Hall University (South Orange, New Jersey) in 1998. The survey's purpose was to collect data that the university's librarian faculty and administration could use to analyze user satisfaction with information services provided through the Web. Seton Hall classroom faculty and students completed 786 questionnaires. About 80 percent of the respondents reported using the Web on a daily or weekly basis. The results revealed valuable information about the Internet users' search strategies and levels of satisfaction with using the Web. ${ }^{4}$

Xue-Ming Bao is an Assistant Professor/Librarian in University Library at Seton Hall University; email: baoxuemi@shu.edu. The author acknowledges the assistance of Arthur W. Häfner, Professor and Dean of the University Libraries, and Richard E. Stern, Associate Professor, Coordinator of Reference Services and Chair of the Library Home Page Task Team, for their critical reviews and helpful comments. 
Seton Hall University Library's home pages had experienced many positive changes since 1998. For example, they provided access to more academic subscription databases in 2001 than they had three years earlier; the design of the library home pages reflected more of the collective wisdom of the librarians; and a larger assortment of interactive library Web forms were provided. The new changes in the library home pages raise two key questions: How do the new changes meet the needs of students and faculty at Seton Hall University? and What strategies should Seton Hall University librarians pursue to improve library services through the home pages?

\section{Purpose}

The purpose of the 2001 survey was to collect data that Seton Hall University librarian faculty and administration could use to analyze library users' Internet search behavior, satisfaction levels, and the needs of the information services provided through the library's home pages. This study is a descriptive survey and a follow-up to the 1998 survey. ${ }^{5}$ The data will provide information on changes in library user habits between 1998 and 2001 . In general terms, the objective of the study is to serve as "an aid ... in planning, improving public relations, and even marketing." 6

\section{Survey Instrument}

The online survey instrument described in this research was pilot-tested by ten people at Seton Hall University: four students, two teaching faculty members, and four librarians and library administrators. It was modified based on their responses and suggestions. The instrument attempted to elicit answers to the following questions repeated from the 1998 survey distributed in paper form:

1. Who is using the Internet and the library's home pages?

2. What are the academic majors or fields of study of the users?

3. How frequently does the user search the Internet?
4. What does the user search for on the Internet?

5. What is the user's satisfaction level with search results?

6. How long does it take for the user to find "satisfactory" results?

7. What problems has the user encountered when searching the Internet?

8. Has the user visited the university library's home pages?

9. Does the user find the university library's home pages helpful in searching the Internet?

10. How does the user find information on the Internet?

11. What are the user's favorite Internet search engine(s)?

12. Academically, whose responsibility is it to teach the user how to search the Internet effectively?

13. What training courses would the user attend?

\section{Data Collection}

In Applied Statistics, John Neter, William Wasserman, and G. A. Whitemore stated that a census of a finite population is a study that includes every element of the population and a census is appropriate when it is easy to reach everyone included in the study. ${ }^{7}$ In Descriptive Statistical Techniques for Librarians, Arthur W. Häfner stated: "Whether the population is sampled or surveyed completely (census), the librarian will want to apply algorithms to reorganize and summarize the raw data." ${ }^{8}$ This author collected the 2001 survey data by means of a census of the $8,000+$ people, including students, faculty, administrators, and staff, on the university's main campus via a direct emailing to their Seton Hall e-mail accounts. The e-mail cover letter provided:

- the researcher's affiliation with the university;

- a brief description of the project;

- a statement of the voluntary nature of the project;

- a statement of anonymity/confidentiality of the subject's data.

People were asked to click on a hypertext link in the e-mail cover letter 
TABLE 1

Percent of Respondents of Different Categories Filling Out the Survey

\begin{tabular}{lrr}
\hline & $\mathbf{1 9 9 8}$ & $\mathbf{2 0 0 1}$ \\
& $\mathbf{n = 7 8 6}$ & $\mathbf{n}=\mathbf{5 8 1}$ \\
\hline Undergraduate & $75.8 \%$ & $57.3 \%$ \\
Graduate & $20.4 \%$ & $18.8 \%$ \\
Faculty & $3.8 \%$ & $8.6 \%$ \\
Admin/Staff & & $10.2 \%$ \\
Other & & $5.2 \%$ \\
\hline
\end{tabular}

to access the online questionnaire. ${ }^{9}$ The online instrument required about five minutes to complete.

The survey e-mail cover letter was sent on January 16, 2001, a week after the beginning of the new spring semester. A total of 581 responses were received, of which 567 were received within the first two weeks of the direct e-mailing and nine were received between the third and fifth weeks. The mass direct e-mailing to $8,000+$ people caused concern within the university's Division of Computing Services because e-mailings for surveys were new to the campus and it was thought that they might clog up the university's e-mail server. The second announcement of the survey was published on February 26, 2001, in the university's community announcement bulletin board. Only five more responses were received after the second announcement. The 2001 online survey yielded fewer responses (581) than the 1998 paper survey did (786). The 1998 survey focused on students and faculty only; the 2001 survey included students, faculty, administrators, and staff. If $8,000+$ were the population, 581 responses represented a low response rate $(7 \%)$.

In Survey Research Methods, Floyd J. Fowler Jr. remarked that a 5 to 20 percent response rate was low but added: "There is no agreed-upon standard for a minimum acceptable response rate.... One generalization that seems to hold up for most mail surveys, though it is inferential, is that people who have a particular interest in the subject matter or the research itself are more likely to return mail questionnaires than those who are less interested. This means that mail surveys with low response rates may be biased significantly in ways that are related directly to the purposes of the research." 10 With this caution in mind, the author qualified the survey projection to the students, faculty, administrators, and staff who are interested in using the Internet only, rather than the entire population of Seton Hall University.

To analyze the data, the Statistical Package for the Social Sciences (SPSS) was employed. Data from the survey instruments were coded and subjected to SPSS. Frequency tabulations were applied to obtain descriptive measures of the responses.

\section{Results \\ User Demographics}

Table 1 shows that 786 people completed the paper survey instrument in 1998 and 581 completed the online survey instrument in 2001. In 1998, print survey instruments were sent to the teaching faculty via campus mail to be distributed to students. Therefore, administrators and staff were not included in the 1998 survey. In 2001, the online survey form's URL was sent to all people with a Seton Hall e-mail account so that administrators and staff were able to participate in the survey. Because the exact responses of the two

\begin{tabular}{|lrc|}
\hline \multicolumn{3}{|c|}{$\begin{array}{c}\text { TABLE 2 } \\
\text { Percent of Respondents' Academic } \\
\text { Major or Field }\end{array}$} \\
\hline \multicolumn{3}{|c}{} \\
& $\mathbf{1 9 9 8}$ & $\mathbf{2 0 0 1}$ \\
$\mathbf{n}=\mathbf{7 8 6}$ & $\mathbf{n}=\mathbf{5 8 1}$ \\
\hline Arts \& Sciences & $44.7 \%$ & $44.4 \%$ \\
Business & $23.3 \%$ & $16.4 \%$ \\
Diplomacy & $0.1 \%$ & $2.8 \%$ \\
Education & $18.2 \%$ & $14.6 \%$ \\
Medical Education & $4.1 \%$ & $3.3 \%$ \\
Nursing & $5.2 \%$ & $2.1 \%$ \\
Theology & $1.7 \%$ & $2.6 \%$ \\
Other & $2.7 \%$ & $13.9 \%$ \\
\hline
\end{tabular}




\begin{tabular}{|lrr|}
\hline \multicolumn{3}{|c|}{ TABLE 3 } \\
Percent of Respondents' \\
Frequency of Using the World \\
Wide Web on the Internet \\
\hline \multicolumn{3}{|c}{} \\
& $\mathbf{1 9 9 8}$ & $\mathbf{2 0 0 1}$ \\
& $\mathbf{n}=\mathbf{7 8 6}$ & $\mathbf{n = 5 8 1}$ \\
\hline Daily & $40.2 \%$ & $84.3 \%$ \\
Weekly & $38.3 \%$ & $10.5 \%$ \\
Monthly & $10.7 \%$ & $0.9 \%$ \\
Seldom & $6.6 \%$ & $0.3 \%$ \\
Other & $2.7 \%$ & $13.9 \%$ \\
\hline
\end{tabular}

surveys are different, it is only meaningful to compare percentages of the responses rather than the exact counts of the responses. A higher percentage of faculty $(8.6 \%)$ participated in the online survey in 2001 than in the paper survey in 1998 (3.8\%). Undergraduate participation dropped in 2001 (57.3\%), compared to 1998 (75.8\%). However, the response distribution of the people in different categories represented the population of Seton Hall University in approximate proportions in both the 1998 and 2001 surveys.

Table 2 shows that in both surveys, majority responses were from three academic majors: Arts \& Sciences $(44.7 \%$ in $1998 ; 44.4 \%$ in 2001$)$, Business $(23.3 \%$ in $1998 ; 16.4 \%$ in 2001$)$, and Education $(18.2 \%$ in $1998 ; 14.6 \%$ in 2001$)$. Other responses from academic majors included Nursing $(5.2 \%$ in $1998 ; 2.1 \%$ in 2001$)$, Graduate Medical Education $(4.1 \%$ in $1998 ; 3.3 \%$ in 2001$)$, Theology $(1.7 \%$ in $1998 ; 2.6 \%$ in 2001$)$, and Diplomacy $(0.1 \%$ in $1998 ; 2.8 \%$ in 2001). The "other" category's percentages increased from 2.7 percent in 1998 to 13.9 percent in 2001 due to the participation of administrators and staff in the 2001 survey.

\section{Internet Use Frequency and Satisfaction Levels}

Table 3 shows that daily use of the Web doubled in 2001 $(84.3 \%)$, compared to 1998 $(40.2 \%)$. Weekly use $(38.3 \%$ in

\begin{tabular}{|c|c|c|}
\hline \multicolumn{3}{|c|}{$\begin{array}{c}\text { TABLE } 4 \\
\text { Percent of Respondents } \\
\text { Searching Information Related } \\
\text { to Academic Studies or Not Related } \\
\text { to Academic Studies }\end{array}$} \\
\hline & $\begin{array}{c}1998 \\
n=786\end{array}$ & $\begin{array}{c}2001 \\
n=581\end{array}$ \\
\hline $\begin{array}{l}\text { Information related } \\
\text { to academic studies } \\
\text { Information not related } \\
\text { to academic studies }\end{array}$ & $83.2 \%$ & $88.1 \%$ \\
\hline
\end{tabular}

$1998 ; 10.5 \%$ in 2001 ) and monthly use $(10.7 \%$ in $1998 ; 0.9 \%$ in 2001$)$ declined sharply in 2001. Almost no one claimed "seldom" use of the Internet in the 2001 survey $(0.3 \%)$, compared to $1998(6.6 \%)$.

Table 4 shows that respondents searched the Internet for information related to both their academic $(83.2 \%$ in $1998 ; 88.1 \%$ in 2001) and nonacademic studies $(73.9 \%$ in $1998 ; 81.6 \%$ in 2001$)$, with a slight increase in both categories in 2001.

Using a scale of five levels of satisfaction, where one indicates the highest and five the lowest, table 5 shows that the respondents' levels of satisfaction for Internet search results increased substantially. In 1998, only 7.8 percent of respondents indicated a high level of satisfaction, compared to 18.1 percent in 2001. In $1998,36.1$ percent rated their satisfaction for Internet search results as level two, compared to 43.0 percent in 2001 . In contrast, the percentages of satisfaction lev-

\begin{tabular}{|c|c|c|}
\hline \multicolumn{3}{|c|}{$\begin{array}{c}\text { TABLE } 5 \\
\text { Percent Of Respondents' Levels Of Satisfaction } \\
\text { For Internet Search Results } \\
\end{array}$} \\
\hline & $\begin{array}{c}1998 \\
n=786\end{array}$ & $\begin{array}{c}2001 \\
n=581\end{array}$ \\
\hline 1 (High Satisfaction) & $7.8 \%$ & $18.1 \%$ \\
\hline 2 & $36.1 \%$ & $43.0 \%$ \\
\hline 3 & $37.0 \%$ & $27.4 \%$ \\
\hline 4 & $11.8 \%$ & $6.4 \%$ \\
\hline 5 (Low Satisfaction) & $3.1 \%$ & $1.2 \%$ \\
\hline
\end{tabular}


els three $(37.0 \%$ in $1998 ; 27.4 \%$ in 2001$)$, four $(11.8 \%$ in $1998 ; 6.4 \%$ in 2001$)$, and five $(3.1 \%$ in $1998 ; 1.2 \%$ in 2001$)$ all decreased substantially.

\section{Internet Search Results and Problems}

Table 6 shows that more respondents were able to obtain satisfactory search results within a short period. In 1998, only 5.0 percent of respondents achieved satisfactory results in less than ten minutes, compared to 10.0 percent in 2001. In 1998, 23.5 percent of respondents spent 11 to 20 minutes, compared to 24.1 percent in 2001 . However, the percent of respondents spending twenty minutes or more to obtain satisfactory search results decreased in 2001: 30.7 percent spent 21 to 30 minutes in 1998, compared to 28.9 percent in 2001; and 33.6 percent in 1998 spent 30 minutes or more, compared to 31.7 percent in 2001.

Table 7 identifies three major problems encountered by users when searching the Internet:

- do not find information needed (49.2\% in $1998 ; 54.7 \%$ in 2001 );

- no full-text information can be cited for academic study and/or research (43.8\% in $1998 ; 52.8 \%$ in 2001 );

- too many hits (38.4\% in 1998; $50.1 \%$ in 2001).

\section{Use of the University Library Home Page}

Table 8 shows that less than half of the respondents (41.3\% in 1998) visited the li-
TABLE 6

Percent Of Respondents' Time

Spent On Searching Satisfactory Results Per Session

\begin{tabular}{lrr}
\hline \hline & $\begin{array}{c}\mathbf{1 9 9 8} \\
\mathbf{n}=\mathbf{7 8 6}\end{array}$ & $\begin{array}{c}\mathbf{2 0 0 1} \\
\mathbf{n}=\mathbf{5 8 1}\end{array}$ \\
\hline 5-10 minutes & $5.0 \%$ & $10.0 \%$ \\
$11-20$ minutes & $23.5 \%$ & $24.1 \%$ \\
$21-30$ minutes & $30.7 \%$ & $28.9 \%$ \\
$31+$ minutes & $33.6 \%$ & $31.7 \%$ \\
\hline
\end{tabular}

brary home page; however, the percentage increased to 71.1 percent in 2001 when conducting their research.

Table 9 shows that out of the 41.3 percent of respondents who accessed the library home page in 1998, 19.2 percent found it helpful, 13.7 percent found it somewhat helpful, 5.3 percent found it very helpful, and 2.5 percent found it not helpful. In 2001, more respondents viewed the library home page in a favorable way. Of the 71.1 percent of the respondents who accessed the library home page in 2001, 32.9 percent found it helpful, 23.8 percent found it somewhat helpful, 11.2 percent found it very helpful, and 3.8 percent found it not helpful.

\section{Internet Search Strategies}

Table 10 shows that using Internet search engines was the preferred way for respondents to search the Internet in both $1998(83.6 \%)$ and 2001 (84.7\%), followed by directly entering a URL or Web address $(63.9 \%$ in $1998 ; 69.5 \%$ in 2001$)$. The percentage of respondents using categorized gateway Internet resource listings (e.g., the library's Web listings by subject) doubled from 17.8 percent in 1998 to 33.6 percent in 2001 . The percentage of respondents using academic subscription databases tripled from 12.1 percent in 1998 to 41.7 percent in 2001. 


\begin{tabular}{|ccc|}
\hline \multicolumn{4}{|c|}{$\begin{array}{c}\text { TABLE 8 } \\
\text { Percent of Respondents Using } \\
\text { the Library's Home Pages } \\
\text { <http://library.shu.edu/> }\end{array}$} \\
\hline \hline & $\mathbf{1 9 9 8}$ & $\mathbf{2 0 0 1}$ \\
& $\mathbf{n = 7 8 6}$ & $\mathbf{n}=\mathbf{5 8 1}$ \\
\hline Yes & $41.3 \%$ & $71.1 \%$ \\
No & $54.3 \%$ & $24.8 \%$ \\
\hline
\end{tabular}

Table 11 shows that Yahoo remained the favorite Internet search engine among the respondents in 2001 (69.7\%); however, the percentage dropped sharply in comparison with 80.5 percent in 1998 . The search engines that increased the percentage of users included: Alta Vista $(27.6 \%$ in $1998 ; 34.6 \%$ in 2001$)$, Excite $(27.7 \%$ in $1998 ; 33.2 \%$ in 2001$)$, Lycos (17.0\% in 1998 ; $33.9 \%$ in 2001$)$, Hotbot (3.8\% in 1998 ; $17.6 \%$ in 2001), and MetaCrawler $(2.3 \%$ in $1998 ; 7.4 \%$ in 2001). The search engines that decreased the percentage of users included InfoSeek (36.1\% in 1998; $24.6 \%$ in 2001) and WebCrawler (19.6\% in 1998; $11.2 \%$ in 2001). The following three search engines that were either not on the 1998 survey or not available in 1998 were used in 2001 by more than 20 percent of the respondents: Ask Jeeves (31.2\%), Netscape $(29.4 \%)$, and Google (25.8\%).

The need for subscription database training increased from 24.4 percent in $\mathbf{1 9 9 8}$ to 32.9 percent in 2001.

\section{Internet Search Training}

Table 12 shows the opinions of respondents concerning which persons or agencies within the university should be responsible for teaching how to search the Internet effectively. The responses included:

- academic college (39.4\% in 1998; $32.2 \%$ in 2001);

- university computing services (44.5\% in $1998 ; 44.2 \%$ in 2001 );

- university librarian faculty (18.7\% in $1998 ; 28.4 \%$ in 2001$)$;

- other $(15.8 \%$ in $1998 ; 16.4 \%$ in 2001).
Table 13 identifies which Internet training courses the respondents would likely attend if the courses were offered by the librarian faculty. Respondents indicated that they were most interested in learning advanced Internet searching skills in both 1998 (55.2\%) and 2001 (52.3\%). The percentage for basic Internet search training dropped from 44.1 percent in 1998 to 21.0 percent in 2001 . The percentage for academic subscription database training increased from 24.4 percent in 1998 to 32.9 percent in 2001. The percentages for the training of gateway Internet resource listings remained more or less the same $(30.5 \%$ in $1998 ; 29.8 \%$ in 2001$)$.

\section{Discussion}

In the report of the 1998 survey, the author discussed three challenges faced by Seton Hall University librarians in view of the 1998 data. ${ }^{11}$ This section discusses how these three challenges have been met in comparison with the 2001 survey data.

\section{The Challenge Met with Visible Improve- ments}

The 1998 survey revealed that the main challenge for Seton Hall University librarians appeared to be how to raise the users' level of satisfaction when providing information services through the Internet. This challenge has been met with visible improvements in the categories of high level of satisfaction and high-speed searching for satisfactory results. In 1998, only 7.8 percent of the respondents indicated a high level of satisfaction with the

\section{TABLE 9}

Percent of Respondents' Opinions on the Library's Home Pages in Facilitating Searching of the Internet

\begin{tabular}{lcc}
\hline \hline & $\mathbf{1 9 9 8}$ & $\mathbf{2 0 0 1}$ \\
& $\mathbf{n = 7 8 6}$ & $\mathbf{n}=\mathbf{5 8 1}$ \\
\hline Very helpful & $5.3 \%$ & $11.2 \%$ \\
Helpful & $19.2 \%$ & $32.9 \%$ \\
Somewhat helpful & $13.7 \%$ & $23.8 \%$ \\
Not helpful & $2.5 \%$ & $3.8 \%$ \\
\hline
\end{tabular}




\begin{tabular}{|c|c|c|}
\hline \multicolumn{3}{|c|}{$\begin{array}{c}\text { TABLE } 10 \\
\text { Percent of Respondents Searching the Internet } \\
\text { in Different Ways }\end{array}$} \\
\hline & $\begin{array}{c}1998 \\
n=786\end{array}$ & $\begin{array}{c}2001 \\
n=581\end{array}$ \\
\hline Very helpful & $5.3 \%$ & $11.2 \%$ \\
\hline Use Internet search engines & $83.6 \%$ & $84.7 \%$ \\
\hline Type in a Web address directly & $63.9 \%$ & $69.5 \%$ \\
\hline $\begin{array}{l}\text { Use categorized gateway Internet } \\
\text { resource listings }\end{array}$ & $17.8 \%$ & $33.6 \%$ \\
\hline Use subscription databases & $12.1 \%$ & $41.7 \%$ \\
\hline Other & $2.3 \%$ & $3.6 \%$ \\
\hline
\end{tabular}

The Challenge Met with Moderate Improvement

The percentage of respondents who believed that responsibility for teaching Internet searching belongs to university computing services and/or to individual academic colleges remained more or less the same, around 40 percent in both 1998 and 2001. The percentage of respondents who believed that responsibility for teaching

Internet; the percentage more than doubled to 18.1 percent in 2001. In 1998, only 5 percent of the respondents were able to obtain satisfactory results within five to ten minutes; again, the percentage doubled in 2001 to 10 percent. However, the percentages in the middle and low levels of satisfaction and eleven minutes or more for satisfactory search results remained more or less the same with a slight change toward a positive direction.

The Internet continued to be an important source of information for academic studies as evidenced by its daily use, which increased from 40.2 percent in 1998 to 84.3 percent in 2001. About 10 percent of the respondents self-identified as having seldom or never used the Internet in 1998; the percentage diminished to 0.3 percent in 2001.

The university library home pages have been accepted and used by more and more respondents. The percentage of respondents using the library's home pages (<http://library.shu.edu $>$ ) increased from 41.3 percent in 1998 to 71.1 percent in 2001. The percentage of respondents' opinions on the library's home pages in terms of facilitating Internet search in the category of "very helpful" increased from 5.3 percent in 1998 to 11.2 percent in 2001; the percentages in the categories of "helpful" and "somewhat helpful" increased from 32.9 percent in 1998 to 56.7 percent in 2001.
Internet searching belongs to university librarian faculty increased from 18.7 percent in 1998 to 28.4 percent in 2001. This

\begin{tabular}{|c|c|c|}
\hline \multicolumn{3}{|c|}{$\begin{array}{c}\text { TABLE } 11 \\
\text { Percent of Respondents' Favorite } \\
\text { Internet Search Engines } \\
\end{array}$} \\
\hline & $\begin{array}{c}1998 \\
n=786\end{array}$ & $\begin{array}{c}2001 \\
\mathrm{n}=\mathbf{5 8 1}\end{array}$ \\
\hline About & & $5.2 \%$ \\
\hline Allthesites & & $1.5 \%$ \\
\hline Alta Vista & $27.6 \%$ & $34.6 \%$ \\
\hline Ask Jeeves & & $31.2 \%$ \\
\hline Business Web & & $1.5 \%$ \\
\hline DrKoop & & $2.1 \%$ \\
\hline Economic Indicator & & $0.7 \%$ \\
\hline Excite & $27.7 \%$ & $33.2 \%$ \\
\hline FindLaw & & $4.6 \%$ \\
\hline Google & & $25.8 \%$ \\
\hline Hotbot & $3.8 \%$ & $17.6 \%$ \\
\hline Inference Find & & $1.2 \%$ \\
\hline InfoSeek & $36.1 \%$ & $24.6 \%$ \\
\hline Look Smart & & $6.2 \%$ \\
\hline Lycos & $17.0 \%$ & $33.9 \%$ \\
\hline Magellan & & $4.5 \%$ \\
\hline MetaCrawler & $2.3 \%$ & $7.4 \%$ \\
\hline Netscape & & $29.4 \%$ \\
\hline Northern Light & & $6.9 \%$ \\
\hline RefDesk & & $2.1 \%$ \\
\hline Skworm & & $0.5 \%$ \\
\hline Snap & & $3.4 \%$ \\
\hline WebCrawler & $19.6 \%$ & $11.2 \%$ \\
\hline Yahoo & $80.5 \%$ & $69.7 \%$ \\
\hline Other & $3.2 \%$ & $11.2 \%$ \\
\hline
\end{tabular}




\begin{tabular}{|c|c|c|}
\hline \multicolumn{3}{|c|}{$\begin{array}{c}\text { TABLE } 12 \\
\text { Percent of Respondents' Opinions on Who } \\
\text { Should Be Responsible for Teaching Them How } \\
\text { to Search the Internet Effectively }\end{array}$} \\
\hline & $\begin{array}{c}1998 \\
n=786\end{array}$ & $\begin{array}{c}2001 \\
\mathrm{n}=\mathbf{5 8 1}\end{array}$ \\
\hline Academic college & $39.4 \%$ & $32.2 \%$ \\
\hline University computing services & $44.5 \%$ & $44.2 \%$ \\
\hline University librarian faculty & $18.7 \%$ & $28.4 \%$ \\
\hline Other & $15.8 \%$ & $16.4 \%$ \\
\hline
\end{tabular}

their professional training to improve their own Internet search skills in order to maintain an edge in the opinions of students, faculty, administrators, and staff as Webbased information search specialists.

\section{Conclusions}

The comparison of the survey data between 1998 and 2001 shows that the Internet

may be the result of the librarian faculty's continuing discussions within the academic community to make sure that this area of teaching is their responsibility.

\section{The Challenge Met with No Improvement}

The three major problems that did not improve or "worsened" for respondents when searching the Internet were as follows: do not find information needed $(49.2 \%$ in $1998 ; 54.7 \%$ in 2001$)$, no full-text information can be cited for academic study and/or research (43.8\% in 1998; $52.8 \%$ in 2001 ), and too many hits (38.4\% in $1998 ; 50.1 \%$ in 2001). These percentages of the 2001 survey are puzzling. With the increase in the library's subscription to Web-based periodical and newspaper databases, one would speculate that the percentage of respondents who may encounter these problems would be lower in 2001 than in 1998. However, the training needs of the respondents may provide some clues. The need for subscription database training increased from 24.4 percent in 1998 to 32.9 percent in 2001. This may mean that librarians need to focus their training on subscription databases, advanced Internet search skills, and useful curricula-related Web resources. Basic Internet search skills are not in demand because the surveys show that the percentage dropped from 44.1 percent in 1998 to 21.0 percent in 2001. The librarians need to keep up with continues to be an important component of library services in today and tomorrow's library. The majority of the respondents used the Internet on a daily basis in 2001, as opposed to less than half the respondents in 1998. The strategies of reallocating library budget resources and improving the design of the university library home pages collectively may have worked in increasing the library users' levels of satisfaction and in attracting more library users to use the library home pages. The librarians' proactive initiatives with the classroom teaching faculty also may have worked to improve the respondents' opinions of the librarians' role in teaching Internet searching.

The survey data show that the librarian's major challenge in the new century remains that of how to help library users find what they are looking for through the Internet. Library users need to know what subscription academic databases and what high-quality free Web

\begin{tabular}{|c|c|c|}
\hline \multicolumn{3}{|c|}{$\begin{array}{c}\text { TABLE } 13 \\
\text { Percent of Respondents Who Would Likely } \\
\text { Attend Internet Training Courses Offered by the } \\
\text { University Librarian Faculty } \\
\end{array}$} \\
\hline & $\begin{array}{c}1998 \\
n=786\end{array}$ & $\begin{array}{c}2001 \\
\mathrm{n}=581\end{array}$ \\
\hline Academic college & $39.4 \%$ & $32.2 \%$ \\
\hline Basic Internet searching & $44.1 \%$ & $21.0 \%$ \\
\hline Advanced Internet searching & $55.2 \%$ & $52.3 \%$ \\
\hline Gateway Internet resource listings & $30.5 \%$ & $29.8 \%$ \\
\hline Subscription databases & $24.4 \%$ & $32.9 \%$ \\
\hline
\end{tabular}


resources are available for them to search and how to search these databases and Web resources effectively and efficiently. This suggests that librarians need to fo- cus on opportunities for providing training on subscription academic databases, advanced Internet search skills, and useful curricular Web resources.

\section{Notes}

1. Mary J. Lynch, Electronic Services in Academic Libraries: ALA Survey Report (Chicago: ALA, 1996).

2. Mick O'Leary, "New Academic Information Model Bypasses Libraries," Online 25 (July/ Aug. 2001): 72-74.

3. Mark Y. Herring, "10 Reasons Why the Internet Is No Substitute for a Library," American Libraries 32, no. 4 (Apr. 2001): 76-78.

4. Xue-Ming Bao, "Challenges and Opportunities: A Report of the 1998 Library Survey of Internet Users at Seton Hall University," College E Research Libraries 59 (Nov. 1998): 535-43.

5. Helen M. Gothberg, "Library Survey: A Research Methodology Rediscovered," College $\mathcal{E}$ Research Libraries 51 (Nov. 1996): 553-59. In this article, Gothberg stated: "Most descriptive surveys describe one library or a group of libraries within a system or even a state. Such surveys deal with quantitative data and are used to compare with similar statistics from the previous year, or other libraries. They may also seek opinions and/or demographic data about users."

6. Ibid.

7. John Neter, William Wasserman, and G.A. Whitemore, Applied Statistics (Boston: Allyn and Bacon, 1982), 188.

8. Arthur W. Häfner, Descriptive Statistical Techniques for Librarians, 2nd ed. (Chicago: ALA, 1998), 6 .

9. http://pirate.shu.edu/ baoxuemi/SHU_library_survey_2001_cover_letter.htm. Accessed on Nov. 25, 2001.

10. Floyd J. Fowler Jr., Survey Research Methods (Newbury Park, Calif.: Sage, 1993), 40-41.

11. Bao, "Challenges and Opportunities." 